\title{
Comparison of ISO 14001:2015 and ISO 45001:2018 Implementation in Coal Mining Sector (Case Study: PT Adaro Energy Tbk, PT Toba Bara Sejahtera Tbk, and PT Indo Tambangraya Megah Tbk
}

\author{
Filson Maratur Sidjabat ${ }^{1}$, Aura Ryumandhina Aninditya Rahardjo Putri ${ }^{1}$, Winda \\ Oktaviani ${ }^{1}$ \\ 1) Faculty of Engineering, Environmental Engineering Department, President University \\ Jl. Ki Hajar Dewantara \\ Kota Jababeka, Cikarang, Bekasi - Indonesia 17550 \\ Email: fmsidjabat@president.ac.id, aura.putri@student.president.ac.id, \\ winda.oktaviani@student.president.ac.id
}

\begin{abstract}
Coal mining is one of the most developed industrial sectors in Indonesia. The quality of natural mineral resources spread across several islands makes Indonesia the 4th coal-producing country globally. The main component in the coal mining industry activity is changing land and changing the landscape, which causes a high potential impact on the environment, social and community economy. Apart from having a direct effect on the ground, the mining industry is an activity that has a high risk of accidents that result in human injury to death. Therefore, occupational safety and health (K3) are essential centres of attention in the mining industry. ISO 45001 and ISO 14001 are international standard certifications that become a component of a company in testing OHS control and environmental management, respectively. Qualitative methods are applied to investigate what programs PT Adaro Energy Tbk, PT Toba Bara Sejahtera Tbk, and PT Indo Tambangraya Megah Tbk in implementing ISO 45001 and ISO 14001 through several updated documents that will be analyzed and presented in tables. And the result is that Adaro Energy and Indo Tambangraya Megah Tbk have carried out various types of programs to control the environment and prevent accidents for their workers. Meanwhile, Toba Bara needs to improve environmental programs and tighten activities related to training to avoid accidents during operations.
\end{abstract}

Keywords: Coal, environment, ISO 45001, ISO 14001

\section{ABSTRAK}

Tambang batu bara merupakan salah satu sektor industri yang paling berkembang di Indonesia. Kualitas sumber daya mineral alam yang tersebar di beberapa pulau menjadikan Indonesia sebagai negara penghasil batubara ke-4 di dunia. Instrumen utama dalam kegiatan industri pertambangan batubara adalah perubahan lahan dan perubahan bentang alam yang menimbulkan potensi dampak yang tinggi terhadap lingkungan, sosial dan ekonomi masyarakat. Selain berdampak langsung ke lapangan, industri pertambangan merupakan kegiatan yang memiliki risiko kecelakaan yang tinggi dari cedera hingga meninggal dunia. Oleh karena itu, keselamatan dan kesehatan kerja (K3) menjadi pusat perhatian penting dalam industri pertambangan. ISO 45001 dan ISO 14001 masingmasing merupakan sertifikasi standar internasional yang menjadi komponen perusahaan dalam pengujian pengendalian K3 dan pengelolaan lingkungan. Metode kualitatif diterapkan dalam penelitian ini untuk mengetahui program apa saja yang dimiliki PT. Adaro Energy, PT Toba Bara Sejahtera, dan PT Indo Tambangraya Megah Tbk dalam menerapkan ISO 45001 dan ISO 14001 melalui beberapa dokumen terupdate yang akan dianalisa dan disajikan didalam tabel. Didapatkan Adaro Energy dan Indo Tambangraya Megah Tbk telah melaksanakan berbagai jenis program pengendalian lingkungan dan pencegahan kecelakaan bagi pekerja. Sementara itu, Toba Bara perlu meningkatkan program lingkungan dan memperketat kegiatan terkait pelatihan agar tidak terjadi kecelakaan saat beroperasi.

Kata kunci: Batu bara, ISO 14001, ISO 45001, lingkungan 


\section{Introduction}

The industry is a collection of several companies with the same goal: producing goods from raw materials and distributing them. Law of the Republic of Indonesia Number 3 of 2014 about Industry, Article 1 states that industry are forms of economic activity that proceed raw materials and utilize industrial resources for producing goods that have added value or higher benefits, including industrial services. Rapid environmental degradation disturbs the government and communities in mining areas, then mining environmental regulations are applied in many countries (Qi, Rui et al, 2020).

One of the supporting sectors of the economy in Indonesia is mining activities (Devy \& Sarungallo, 2018). There are many small coal reserves on Sulawesi, Papua, Sumatra, Java and Kalimantan islands. With many coal sources scattered in Indonesia, following the International Energy Agency (IEA) in 2018, Indonesia is ranked 4th as the largest coal-producing country globally. Although it has to compete with China, India and the United States, Indonesia has good potential in the coal mining sector. Therefore, many companies are engaged in this field to take advantage of the natural resources that exist in Indonesia. Several mining companies in Indonesia already have reached their final stage, where several had the post-closure stage, which requires strong regulation in the environmental sector to ensure the reclamation and rehabilitation is well conducted (Dwiki, 2018).

In the implementation of the coal industry, special monitoring is required, which includes all mining activities. The existence of certification can realize this carried out by the competent body. In addition to gaining confidence in the quality of services or products, the company must have a certificate to ensure that all mining activities do not pollute the surrounding environment. The company's environmental quality must be considered due to activities that possibly change the environmental conditions to a bad one. This will have an impact on the quality of people living around the mine. Coal mining causes both air and water pollution, primarily coal gangue and coal mine gas and mine water removal, that can cause surface subsidence and soil erosion ( $\mathrm{Li}$, Ying et al, 2019). Another certificate that mining companies need to have been the safety of their workers. It is known that this mining activity is very vulnerable to worker safety. Although several theoretical frameworks are available to study supervisory leadership in the mining industry, this study adopted a social support lens to frame the analysis (Haas, E.J., 2020).

One of the international standards engaged in workplace safety and environmental quality is ISO 45001:2018 and ISO 14001:2015. ISO issues standards with decentralization, the existence of special committees and working groups representing certain industries, research institutions, government authorities, consumer organizations, and internationally qualified organizations from around the world (Rizka et al, 2019). ISO 45001:2018 is an international standard that specifies requirements for a management system's health and safety, enabling an organization to work with attention to performance in preventing occupational accidents and occupational diseases. This certificate is an upgrade from OHSAS 18001: 2007, which means there is an increase in the guidelines for implementing health and safety in the workplace. The existence of ISO 45001 will provide benefits for health and safety professionals. As part of preparing for certification to comply with the requirements of the ISO 45001 standard, an assessment of OSH risks and opportunities was carried out at an open-pit mine (Rudakov et al, 2021). Release of the new standard ISO 45001 (2018) represents the last step in a long evolution process of integrated management systems (Darabont et al, 2018). The importance of ISO 45001 also lies in its approach to risk and harm to all factors that can lead to illness, injury, and in some extreme cases, death. ISO 45001 proves that this standard takes into account not only physical damage but also long-term health.

Since the 1980s, issues related to environmental pollution have been increasing, several policies have been made in parts of the country regarding how human care is for the environment, and even the government has made written rules related to the environment (Zikri \& Sidjabat, 2019). Meanwhile, ISO 14001 deals with the process of an organization managing environmental management. Organizations that have an ISO 14001 certificate can say they care about environmental quality to protect the environment and minimize activities that hurt the condition of the surrounding environment. The goal of ISO 14001 is to build a good image of an organization or company in the community's eyes by taking into account the quality of the environment around it. ISO 14001 certified organizations have managed natural resources wisely and adequately. This will trigger eco-efficient management, which will affect the quantity of waste from production. Also, implementing ISO 14001:2015 will give benefit to the company (Givano \& Sholichah, 2019). 
Several companies run in coal mining in Indonesia with ISO 45001 and ISO 14001 certifications include PT Adaro Energy, PT Toba Bara Sejahtera, and PT Indo Tambangraya Megah. Apart from being certified to the international standards above, the three companies also have ISO 9001, which deals with production quality management. The coal mining company licensed above shows that the company already has a sound management system in the environment and work safety.

This study aims to analyze the implementation of ISO 14001:2015 and ISO 45001:2018 by comparing three industries in the same sector: the coal mining industry. The comparison will show the industry's activity and strategy to achieve and apply ISO regulation in quality management systems. Also, form the case studied, the challenges that exist in the implementation of ISO will be explained (Gunawan et al, 2020).

\section{Method}

The presented publication deals with the issue of relations between selected industry 22 standards that make up an integrated management system (Wolniak, R., 2020). The data were from the business financial reports and the literature study of educational books, research papers, journals, articles, and expert report (Mardawiyah et al, 2020). By using the updated information and data from the above documents, a comparative analysis of the ISO application system will be carried out in each company. Activities carried out by PT Adaro Energy Tbk, PT Toba Bara Sejahtera Tbk, and PT Indo Tambangraya Megah Tbk towards the application of ISO 14001:2015 and ISO 45001:2018. In addition to analysis, this study will also pour the data through tables.

\section{Result and Discussion}

\subsection{Company Profile}

\subsubsection{PT. Adaro Energy Tbk}

Adaro Energy is an energy company consisting of eight subsidiaries: Adaro Water, Adaro Capital, Adaro Mining, Adaro Services, Adaro Logistics, Adaro Power, Adaro Land, and Adaro Foundation. Adaro Energy's leading mine site is located in South Kalimantan. PT Adaro Energy, Tbk did efficiency through integrating service businesses mining and logistics, and so on building electricity businesses (Abdurahman et al, 2020). Adaro Energy also has metallurgical coal assets that range from semi-soft coking coal to premium hard coking coal in Indonesia and Australia. Adaro Energy was founded in 2004, and PT Adaro Strategic Investment holds the largest share at $43.91 \%$, Garibaldi Thohir at $6.18 \%$, and other vital shareholders hold the rest. In 2019, Adaro was proud to receive the Gold PROPER award from the Ministry of Environment and Forestry while maintaining ISO 14001: 2015, the latest ISO 14001: 2008 (PT Adaro Energy, 2019).

\subsubsection{PT. Toba Bara Sejahtera Tbk}

PT Toba Bara Sejahtera Tbk is a large company engaged in mining and coal sector and trading, processing energy and palm oil. This Company has been established since 2007. This company has several shareholders, $61.91 \%$ of which are owned by Highland Strategic Holdings, Pte Ltd. In 2020, PT Toba Bara Sejahtera Tbk changed the company's name to PT TBS Energi Utama Tbk. And this Company will enter the water, electricity and energy business. However, coal mining activities remain the focus of this Company. PT. Toba Bara Sejahtera Tbk has several subsidiary affiliates consisting of, PT Adimitra Baratama Nusantara and subsidiaries, PT Gorontalo Listrik Perdana, PT Main Kalimantan Plantation, PT. Toba Bara Energi and subsidiaries, PT. Toba Bumi Energi and subsidiary, and PT. Main Mineral Trisensa. The Company is one of the bigest warm coal makers in Indonesia. An add-up concession zone of 7,087 hectares comprises three mines found in Sangasanga, Kutai Kartanegara, East Kalimantan. Add up to save and add up to asset are assessed at 147 million tons and 236 million tons individually as per the JORC reports of 2011 and 2012. The 3 mining concessions are worked by 3 backups of PT Trisensa Mineral Utama (TMU), PT Adimitra Baratama Nusantara (ABN) and PT Indomining (IM). PT Toba Bara Sejahtra Tbk also has ISO 9001: 2015 certificate relating to quality management (PT Toba Bara Sejahtera, 2019). 


\subsubsection{PT. Indo Tambangraya Megah Tbk}

PT. Indo Tambangraya Megah is a company that processes and supplies coal energy in the national and international market which was founded in 1987 and continues to grow until now. PT. Indo Tambangraya Megah is known as a company with high corporate governance standards by implementing environmental, health and work safety compliance. The mission aimed at this company is as a nation's energy builder, creating sustainable relationships between stakeholders and creating a sustainable Environment, Social and Economy. PT. Indo Tambangraya Megah has been awarded the blue PROPER predicate from the Indonesian Ministry of Environment according to the Coal Mine Company Performance Valuation Program in Environmental Management Program in 2018/2019. This company has also received ISO 14001: 2015 certificate valid until 2022 and ISO 45001: 2018 certificate until 2020 (Indo Tambangraya Megah Tbk, 2019).

\subsection{ISO 45001:2018}

\subsubsection{Implementation of ISO 45001:2018 PT. Adaro Energy. Tbk}

The scale of mining operations is enormous, making Adaro Energy complete with international standard certificates to ensure its high safety and health performance. To improve its safety management standards in 2019, Adaro Energy is certified with ISO 45001: 2018 as the newest version of OHSAS 18001: 2007. To ensure that all employees work according to the rules and prioritize safety, Adaro Energy has implemented two steps. Since 2017, Adaro Energy has implemented provisions regarding safety management guidelines in running operations. There are at least seven main areas that become the focus for all of Adaro Energy's subsidiaries in managing OHS risks: loading and unloading processes, operation of mobile facilities, application of acceptable mining practices, fire prevention and handling, construction activities, hygiene of food and shelter, and health facilities. Behind the $\mathrm{K} 3$ unique provisioning for all workers in their respective fields, Adaro Energy also has several routine activities related to the OHS sector and occurs in 2019.

1. Safety Culture Survey in Ports, Mines and Power Plants

This survey focuses on the company's safety behaviour in 2019 with the hope of knowing the maturity level of the K3 culture in Adaro Energy's subsidiaries. Analyzing three different places according to their work environment can make it easier for companies to make more effective strategies in forming AZAM (Adaro Zero Accident Mindset).

2. Port Safety Accountability Program

Adaro Energy's HSE team has a Safety Accountability Program at the port by guiding supervisors to understand $\mathrm{OSH}$ management. In this program, supervisors carry out several things such as K3 inspections of all workers in each field, five minutes of conversation (P5M), work safety analysis, and reporting hazard events around the port.

3. Emergency Drills on Operations at Mining Centers

To protect the safety and health of its workers, Adaro Energy continues to provide training related to workers' readiness in dealing with emergencies at work. This emergency exercise intends so that every worker in each department can respond quickly in the face of an emergency. In 2019, all personnel received training regarding what they should do in a severe incident, such as replacement of tires due to overpressure vehicles/equipment, accidents on mining roads, and in the event of a fire at a mining site. Previously in 2018, mining workers collaborated with the BRIGDAL KARHUTLA team to extinguish forest fires in Palangkaraya, Central Kalimantan. Also, they conduct emergency drills for forest and land fires around mining.

4. Physical Work Monitoring

Work accidents can be caused by negligence or poor physical condition of workers. To reduce these risks, the company is applying health for work program to improve the wellness of the employees by exercising before work. Using the Harvard Test, CCTV surveillance and inspection of workers' fitness levels will be measured.

5. OHS Risk Control Workshop 
Adaro Energy also held critical control management workshops in 2019 in several subsidiaries, which aims to provide knowledge regarding risk evaluation that can occur in operations using CCM (See Figure 1).

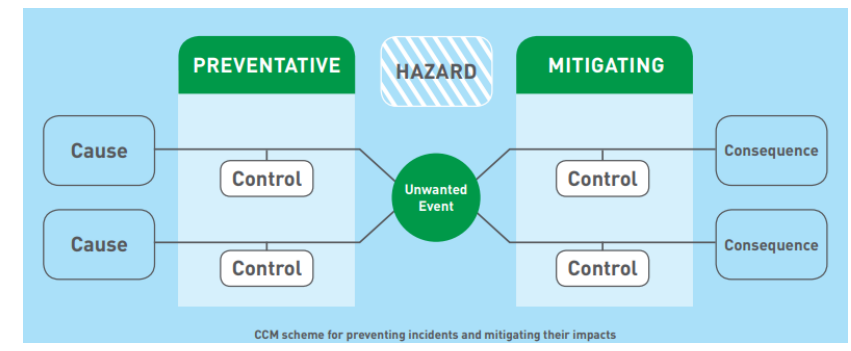

Figure 1. Critical Control Management Flow (PT. Adaro Energy Tbk,.2019)

6. K3 Performance Appraisal Program

There are several parameters that Adaro Energy takes to assess the performance of each of its children in the OSH sector. For example, how they manage the main risks, what percentage refers to the laws and regulations at work, Adaro Group's SMK3 implementation, and the level of work accidents.

\subsubsection{Implementation of ISO 45001:2018 PT. Toba Bara Sejahtera}

From year to year, Toba Bara always tries to improve the safety of his workers when carrying out operations. From 2018 to 2019, Toba Bara has conducted many basic trainings on K3. In addition to training, they also require all employees to carry out emergency response simulations to reduce the risk if an accident occurs. Especially for the $\mathrm{K} 3$ Team, periodically conducts tests of heavy equipment with the aim of reducing any failures during mining operations. There are several programs related to K3 implemented by Toba Bara throughout 2019:

1. Emergency response simulations and various training to support $\mathrm{K} 3$ for supervisors;

2. Fatigue Monitoring related to the operation of heavy equipment;

3. Safety campaign, which means the installation of signs in the area where accidents often occur;

4. Health talk, which means a discussion related to employee health issues.

\subsubsection{Implementation of ISO 45001:2018 PT Indo Tambangraya Megah Tbk}

PT Indo Tambangraya Megah (ITM) has a Health, Safety, Environment, and Community (HSEC) Department, which was established in 2018. Their responsibility is ensuring the implementation of the HSE \& Environmental Management System (HSEMS), Mineral Mining Safety Management System (SMKP Minerba). ITM strives to improve the performance of K3 in the work environment by pushing for the adjustment of K3 management from OHSAS 18001: 2007 and replaced by the latest certification, namely ISO 45001: 2018.

HSE audits are carried out as a reference for assessments and evaluations carried out three times in one year, including internal audits by the HSEC Division, Audit Quality Assurance Reviews for HSE aspects carried out to central agencies, and external audits handled by certification boards (Direktorat Sustainability \& Risk Management PT ITM Tbk, 2019).

\subsection{ISO 14001:2015}

\subsubsection{Implementation of ISO 14001:2015 PT. Adaro Energy. Tbk}

In maintaining environmental quality against pollution, Adaro Energy always controls all the inputs and outputs of each mining activity. Adaro Energy's subsidiaries carry out a number of routine activities to control adverse effects on the environment (Adaro Energy, 2019).

1. Waste Water Quality Management

Adaro Energy sets regulations for all of its subsidiaries regarding the treatment of wastewater. Before being discharged into the river, all wastewater will be treated in 19 
settling ponds. The result of this processing is the number of environmental pollutant parameters following statutory regulations. Adaro Energy's average mining activity wastewater throughout 2019, the values for the five required parameters ( $\mathrm{pH}, \mathrm{TSS}, \mathrm{Fe}, \mathrm{Mn}$, and $\mathrm{Cd}$ ) are under quality standards (see Figure 2 ).

\begin{tabular}{lcc}
\multicolumn{1}{c}{ Parameter } & Average Concentration I Konsentrasi Rata-rata & Effluent Standard I Baku Mutu \\
\hline pHI Derajat Keasaman & 7.72 & $6-9$ \\
\hline $\begin{array}{l}\text { Total Suspended Solid (TSS) } \\
\text { 7at parat tersıspensi }\end{array}$ & $7.24 \mathrm{mg} /$ liter & Max $200 \mathrm{mg} /$ liter \\
\hline Fe | Besi & $0.21 \mathrm{mg} /$ liter & Max $7 \mathrm{mg} /$ liter \\
\hline Mn | Mangan & $0.20 \mathrm{mg} /$ liter & Max $4 \mathrm{mg} /$ liter \\
\hline Cd | Cadmium & $<0.004 \mathrm{mg} /$ liter & Max $0.05 \mathrm{mg} /$ liter \\
\hline
\end{tabular}

Figure 2. The concentration of Environmental Pollutant Parameters (PT. Adaro Energy Tbk,. 2019)

2. Air Quality Management

One of Adaro Energy's subsidiaries in the electricity sector produces emissions from chimneys. These emissions are managed by using an air pollutant controller using an electrostatic precipitator which makes these emissions still meet the stack emission-quality standards by the Minister of Environment and Forestry Regulation Number 15-year 2019 emission standards for thermal power plants. Besides, the HSE and RM divisions produced Technical Guidelines for Air Quality Management and Monitoring to ensure the processing process, which explained guidelines for each operational activity.

3. Hazardous Waste Management

Adaro Energy has a permit to temporarily store B3 waste generated from mining activities before it is handed over to a third party for transportation and processing. However, several types of B3 waste that companies use, such as lubricant waste, are processed into explosives for mining activities. The utilization of this lubricant waste reached 763.97 tons in 2019.

4. Mined Land Reclamation and Watershed Rehabilitation

The reclamation activities, which consist of removing the top layer and removing the layers, are Adaro Energy's actions in maintaining environmental quality. The land will be laid out, and the shoots will be spread out for planting. Then, drainage and drop structures are also installed around the ground to prevent erosion. And the trees that have been prepared will be planted using hydroseeding for cover crops and manual planting for ordinary trees (see Figure 3).

\begin{tabular}{|c|c|c|c|c|}
\hline Description & Satuan I unit & Aktual | Actual & Rencana | Plan & Uraian \\
\hline 1) Land surface setting & ha & 871,84 & 831,60 & Pengaturan permukaan lahan \\
\hline 2) Soil shoots spreading & $m^{3}$ & 868.833 & 623.620 & Penghamparan tanah pucuk \\
\hline $\begin{array}{l}\text { 3) Control of erosion } \\
\text { and water management }\end{array}$ & & & & $\begin{array}{l}\text { Pengendalian erosi dan } \\
\text { pengelolaan air }\end{array}$ \\
\hline - Drainage maintenance & $m^{3}$ & 209.983 & 194.962 & - Pemeliharaan drainase \\
\hline - Drop structure building & unit & 139 & 108 & - Pembangunan drop structure \\
\hline 4) Seedling and nurseries & Pohon I Trees & 157.207 & 72.031 & Persemaian dan pembibitan \\
\hline 5) Revegetation & & & & Revegetasi \\
\hline - Cultivation & ha & 358,52 & 356,83 & - Penanaman \\
\hline - Hydro seeding & ha & 666,81 & 756,00 & - Hydro seeding \\
\hline
\end{tabular}

Figure 3. Table of Rehabilitation and Reclamation Activities - Actual vs. Plan (PT. Adaro Energy Tbk.,2019)

5. Energy Efficiency and Reducing Greenhouse Gas Emission by Adaro Indonesia

Most of Adaro Energy's energy consumption is in mining operations, with biodiesel consumption of 650,000 kiloliters in 2019. Besides, mining operations also consume around 12,000 kiloliters of energy for a $13 \mathrm{MW}$ generator set for Coal Processing and Barge Loading (CPBL) activities. Due to a large amount of energy Adaro Energy uses, an Energy Conservation Opportunity List (Eco-List) has been compiled, responsible for controlling 
greenhouse gas emissions produced from mining operations. The components of the ECO List are:

- Rearrange the generator load in the CPBL process, raise the generator load by up to $65 \%$ by centralizing the generator room;

- Queue arrangement in CPBL, distribution of trailer units per hour;

- Monitoring the accuracy of the trailer unit during low supply operating hours by activating the KM29 rest area;

- Reducing the number of trucks in the mining cycle and improving road conditions to increase the unit speed from $22 \mathrm{~km} / \mathrm{hr}$ to $24 \mathrm{~km} / \mathrm{hr}$.

This ECO List helps companies reduce energy emissions from 2019 to 11.3 litres/tonne of coal from 11.9 litres/tonnes in the previous year. And this is one of Adaro Energy's achievements in obtaining ISO 50001: 2011 certification and recognition from international certification bodies in 2018 .

\subsubsection{Implementation of ISO 14001:2015 PT. Toba Bara Sejahtera}

To support a better environmental program, the company Toba Bara has developed a multi-functional forest area called an arboretum that has around 38 hectares which functions as a place for rare fauna and flora. Such as Orangutans as the subpopulation in the northeastern region in East Kalimantan (Guild, R., 2019). This forest is called virgin forest because of its authenticity which is completely untouched by mining activities. The number of giant trees, the habitat of the flora that live here. This arboretum forest is connected to ex-mining reclaimed land so that its area will continue to grow.

\subsubsection{Implementation of ISO 14001:2015 PT. Indo Tambangraya Megah Tbk}

1. Post Mining Management

One of the ITM sites, the KTD Tidung Mayang site, has stopped mining activities since 2016, and is currently entering post-mining activities which are planned to be completed in 2021. In 2019 , reclamation has been carried out in the plant care sector by $100 \%$ of the post-plan. mine namely $234.72 \mathrm{Ha}$. The reclamation activities carried out have returned the forest area according to its function. Apart from reclamation activities, ITM is also responsible for restoring the economic sector which was previously replaced by mining activities. ITM has provided entrepreneurship training for 417 workers. Meanwhile, the level of independence and community acceptance in the six villages has reached $100 \%$. That activity states in the Post Mining Plan that it was included in the company obligation.

2. Biodiversity Conservation and Reclamation in the Post-Mining Land

Conservation activities are also done in coastal areas located in the Bontang Lestari District and Santan Ilir Village, Kutai Kartanegara Regency. This area is an area prone to abrasion and several areas have a high possibility of sinking when the tide is in. The activities carried out are planting mangrove trees and preserving coral reefs, supporting natural filtering functions and prevent coastal abrasion. The mangrove forest area that was built also aims to be an eco-tourism which then is mutualism to help the community's economy. Realization of Revegetation and Reclamation at Mine Sites can be seen in Figure 4.

\begin{tabular}{lccccr}
\hline $\begin{array}{l}\text { Parameter } \\
\text { Parameter }\end{array}$ & $\begin{array}{r}\text { Satuan } \\
\text { Unit }\end{array}$ & $\begin{array}{r}\text { Akumulasi } \\
\text { Accumulation }\end{array}$ & 2019 & 2018 & 2017 \\
\hline $\begin{array}{l}\text { Lahan Terganggu } \\
\text { Disturbed Area }\end{array}$ & ha & 24,734 & 851 & 827 & 891 \\
\hline $\begin{array}{l}\text { Lahan Reklamasi } \\
\text { Reclaimed Area }\end{array}$ & ha & 12,904 & 876 & 708 & 562 \\
\hline $\begin{array}{l}\text { Lahan Revegetasi } \\
\text { Revegetated Area }\end{array}$ & ha & 12,646 & 826 & 587 & 494 \\
\hline $\begin{array}{l}\text { Jumlah Pohon } \\
\text { Number of Trees }\end{array}$ & $\begin{array}{r}\text { Batang } \\
\text { Trees }\end{array}$ & $7,670,350$ & $1,064,050$ & 741,310 & 682,154 \\
\hline
\end{tabular}

Figure 4. Realization of Reclamation (PT. Indo Tambangraya Megah Tbk.,2019) 


\section{Biodiversity Conservation of the Mining Operation Area}

\section{Watershed Rehabilitation}

The management of watersheds by ITM refers to regulations on watershed rehabilitation by the government and the ministry of environment. ITM carries out a planting program for watershed rehabilitation done in the mining area or beyond the mining area, according to the watershed location permit that the government has stipulated. The watershed rehabilitation plan is carried out for three years under the company's responsibility, including planting (P0) in the first year, maintenance in the first year (P1), and maintenance in the second year (P2). The year after that, it is taken over by the government if it meets the success criteria. In this case, ITM carried out planting in watershed areas in two provinces, including South Kalimantan and East Kalimantan.

\section{Managed Invasive and Original Species in Watersheds}

Rehabilitation of watershed land carried out by ITM aims to manage the ecological impacts of soil and invasive species categorized as reversible. The ecological endemics planted are also diverse using herbicides and thinning. This process took three years and involved 14 local contractors to move the economy of the local population through labor absorption activities.

\section{Preservation of Coastal Area}

Conservation activities are also carried out in coastal areas located in the Bontang Lestari District and Santan Ilir Village, Kutai Kartanegara Regency. This area is an area prone to abrasion, and several areas have a high possibility of sinking when the tide is in. The activities carried out are planting mangrove trees and preserving coral reefs, with the aim of supporting natural filtering functions and preventing coastal abrasion. The mangrove forest area that was built also aims to be an eco-tourism which then is mutualism to help the community's economy.

\section{Energy Management}

By the mandatory program on Biofuel 20 stipulated in Permen ESDM No.12 of 2015, ITM uses energy sources derived from diesel fuel for power generation, heavy equipment operation, and mixing of palm-based biofuels at a level of $20 \%$ since quarter IV 2018. A third party, namely PLN, meets ITM's electrical energy needs for domestic needs. A small portion of the demand is also completed through ITM's coal fired power plant with the capacity of about $2 \times 7 \mathrm{MW}$ from self-produced coal. Energy management is measured by conducting internal energy audits, which a certified independent party then verifies. ITM also develops new sources of energy with renewable energy principles. In 2019 ITM built a solar power plant IMM with $3 \mathrm{MW}$ and targeted will operate in 2020. This program aims to intensify energy efficiency, reduce emissions, and support the SDG's number 13.

\section{Management of GreenHouse Gas (GHG) Emission}

GHG emissions are released through the process of transporting coal and blasting using fossil energy sources. ITM carries out a numerical method in its management and controls GHG emissions by calculating the release of $\mathrm{CO} 2, \mathrm{CH} 4, \mathrm{~N} 2 \mathrm{O}$, and HFCs. The source of ITM's GHG emissions comes from fuel combustion for mobile vehicles, coal-fired power plants, generators, refrigerants and air conditioners, and the PLN Power Plant.

\section{Water Management}

ITM has 65 sediment ponds that are used as pre-treatment before running water into river bodies. The water in the sediment pond is monitored first, based on monitoring the quality of the wastewater and until met quality standard. It is not affecting the habitat in it. Sediment ponds are also used as rainwater storage and run-off controllers to drainage channels, used for watering roads, vehicles, mining facilities, and stockpiles. ITM has a subsidiary coal-fired power plant, IMM, which uses seawater to cool the evaporation process. ITM's domestic activities are filled with groundwater sources and artificial lakes.

\section{Waste Management}

ITM has treated all types of waste generated on the company's premises. The resulting hazardous waste is sent to a third party to be processed under the Ministry of Environment's Decree No. 07.14.03 / 2014 \& Ministry of Environment Decree No.232 / 2013. Meanwhile, non-B3 waste is used as compost and recycled using the 3R principle, Reuse, Reduce, Recycle. Paper waste and plastic waste are given to third parties and landfills for local governments. 


\subsection{Comparison}

Table 1 and 2 shows the comparison between the ISO 45001:2018 and 14001:2015 in each company. From the table shown the differences and characteristics that are applied in each company.

Table 1. Comparison of ISO 45001:2018 Implementation

\begin{tabular}{|l|l|}
\hline \multicolumn{2}{|c|}{ Comparison of ISO 45001 and 14001 implementations between companies } \\
\hline \multicolumn{2}{|c|}{ Implementation of ISO 45001:2018 } \\
\hline PT. Adaro Energy, Tbk & 1. Implementing safety culture survey \\
\hline \multirow{5}{*}{} & 2. Implementing port safety accountability program \\
\cline { 2 - 3 } & 3. Applied physical work monitoring \\
\cline { 2 - 3 } & $\begin{array}{l}\text { 4. Has implement the emergency drills on operation at } \\
\text { mining sites }\end{array}$ \\
\cline { 2 - 3 } & 5. Have OHS risk control workshop \\
\cline { 2 - 3 } & 6. Have K3 performance appraisal program \\
\hline PT. Toba Bara Sejahtera & 1. Has conducted K3 training \\
\hline \multirow{5}{*}{} & 2. Has implement fatigue monitoring \\
\cline { 2 - 3 } & 3. Conducting safety campaign \\
\cline { 2 - 3 } & 4. Have health talk program \\
\hline PT. Indo Tambangraya Megah, Tbk & 1. Have internal and external audit relate to HSE \\
\hline & 2. Has HSEMS employees protection \\
\cline { 2 - 3 } & 3. Campaigning OHS culture \\
\hline
\end{tabular}

Source: Adaro, Toba Bara, ITM Sustainability Report, 2019)

Table 2. Comparison of ISO 14001:2015 implementation

\begin{tabular}{|l|l|}
\hline \multicolumn{2}{|c|}{ Comparison of ISO 45001 and 14001 implementations between companies } \\
\hline \multicolumn{5}{|c|}{ Implementation of ISO 14001:2015 } \\
\hline PT. Adaro Energy, Tbk & 1. Implementing 19 settling ponds to manage wastewater \\
\hline & 2. Applied electrostatic precipitator \\
\cline { 2 - 3 } & 3. Applied hydroseeding for reclamation program \\
\cline { 2 - 3 } & 4. Has implement ECO-List to controlling GHG \\
\cline { 2 - 3 } & 5. Have OHS risk control workshop \\
\hline PT. Toba Bara Sejahtera & 1. Rehabilitate fauna such as Orangutans \\
\hline \multirow{5}{*}{ Tbk. Indo Tambangraya Megah, } & 2. Commit to return the post mining to origin forest \\
\hline \multirow{5}{*}{} & 1. Implement the post mining management \\
\hline & 2. Have reclamation and biodiversity conservation program \\
\cline { 2 - 3 } & $\begin{array}{l}\text { 3. Applied watershed rehabilitation and manage original } \\
\text { species on there }\end{array}$ \\
\cline { 2 - 3 } & 4. Preservation of coastal area \\
\cline { 2 - 3 } & 5. Will apply solar power plant as a renewable energy \\
\cline { 2 - 3 } & 6. Responsible to manage GHG emission \\
\cline { 2 - 3 } & $\begin{array}{l}\text { 7. Implementing } 65 \text { sediment pond and have responsibility to } \\
\text { manage the waste. }\end{array}$ \\
\hline
\end{tabular}

(Source: Adaro, Toba Bara, ITM Sustainability Report, 2019)

\section{Conclusion}

To conclude, the three coal mining companies above already have environmental and $\mathrm{K} 3$ programs which are quite good and support their activity processes. However, they will still continue to develop these programs according to conditions in the field. Especially for Toba Bara, which requires more effort in presenting sustainable programs in the field of environmental control due to mining 
operations. Based (PT Toba Bara Sejahtera Tbk, 2019) several data sources in the form of annual and monthly reports, Toba Bara until 2019, only had 2 activities in the effort to implement ISO 14001: 2015 related to environmental management. Although there are only a few, activities to reduce the intensity of environmental damage to production activities, Toba Bara can be said to have been consistent with its responsibilities, one of which is to commit to ensuring the return of origin forest due to its mining activities.

\section{Acknowledgement}

We are very grateful to Allah SWT, because with his blessings we were able to do this study on time. To a whole of our family who always support us in finding data and compiling data for this study. In addition, we are ecstatic to have friends who always give us encouragement and prayers.

\section{References}

1. Abdurahman, S. G. (2019). Analisis Lingkungan Bisnis PT Adaro Energy, Tbk. Jurnal Bisnis dan Pembangunan, vol. 9, no. 1, 2020, doi: ISSN 2541-1403, E-ISSN 2541-187X.

2. Direktorat Sustainability \& Risk Management PT ITM Tbk. (2019). Change At the Heart of Sustainability.

3. Doru Costin Darabont, ,. C.-A.-S.-R. (2018). Considerations On Improving Occupational Health. Environmental Engineering and Management Journal, vol. 17, no. 11, pp. 2711-2718, 2018, doi: 10.30638/eemj.2018.270.

4. Dwiki, S. (2018). Development of Environmental Policy in Indonesia regarding . Joint Journal of Novel Carbon Resource Sciences \& Green Asia Strategy, Vol. 05, Issue 02, pp.50-57, June 2018.

5. Gilbert Givano, H. S. (2019). Implementation Of Iso 9001:2015 And Iso 14001:2015 In Coal And Heavy Metal Mining Sector: Study Case On Developed And Developing CountrY. Jurnal Sains dan Teknologi Lingkungan, vol. 11, no. November 2018, pp. 57-73, 2019.

6. Giovani, M. a. (2020). MEasuring And Analysing Financial Performance Of Coal Mining Companies Listed On The Indonesia Stock Exchange Before And After The Implementation Of Fast Track Program 35.000 Megawatt Of 2016. South East Asia Journal of Contemporary Business, Economics and Law, , vol. 21, no. 2, pp. 9-25, 2020.

7. Guild, R. (2019). Threats To Wild Orangutans: A Case Study In Kutai National Park Of East Kalimantan, Indonesia. York Space Institutional Repository.

8. Haas, E. J. (2020). The Role of Supervisory Support on Workers' Health and Safety Performance. Health communication, vol. 35, no. 3, pp. 364-374, 2020, doi: 10.1080/10410236.2018.1563033.

9. Marat Rudakov, E. G. (2021). Risk-Based Thinking as a Basis for Efficient Occupational Safety Management in the Mining Industry. Sustain, vol. 13, no. 2, pp. 1-14, 2021, doi: $10.3390 /$ su13020470.

10. Michelle Gunawan, R. A. (2020). Environmental Management System Implementation in MSMEs: A Literature Review. Jurnal Serambi Engineering, vol. 5, no. 2, pp. 1070-1078, 2020, doi: 10.32672/jse.v5i2.1958.

11. PT Adaro Energy. (2019). Adaro Energy Tbk Annual report 2019. PT. Adaro Energy.

12. PT Toba Bara Sejahtera. (2019). Laporan Tahunan dan Annual Report .

13. PT Toba Bara Sejahtera Tbk. (2019). Company Preview (Full-Year).

14. PT. Adaro and Energy Tbk. (2019). Advancing Sustainable Development Through Empowerment and Synergy.

15. PT. Indo Tambangraya Megah. (2019). PT. Indo Tambangraya Megah, Tbk Annual Report.

16. Radoslaw, W. (2020). Quantitative relations between the implementation of industry management systems in European Union countries. Sci. Pap. Silesian Univ. Technol. Organ. Manag. Ser., vol. 2020, no. 145, pp. 635-646, 2020, doi: 10.29119/1641-3466.2020.145.47.

17. Rizka Dwi Apriliani, Y. M. (2019). ISO 14001:2015 and ISO 9001:2015 Implementation in Construction Company Study Case: PT. Adhi Karya (Persero) Tbk, PT. Nusa Kon-struksi Enjiniring 
Tbk, Eiffage, and Acciona, S,A. Jurnal Lingkungan Hidup dan Sipil, vol. 2, no. 2, pp. 126-138, 2019.

18. Rui $\mathrm{Q} i, \mathrm{~T}$. L. (2019). Simulating the sustainable effect of green mining construction policies on coal mining industry of China. Journal of Cleaner Production, vol. 226, no. 2019, pp. 392-406, 2020, doi: 10.1016/j.jclepro.2019.04.028.

19. Shalaho Dina Devy, S. C. (2018). Groundwater aquifer study on coal mining area: a case of North Samarinda, Indonesia. Journal of Degraded and Mining Lands Management; Malang, Vol. 6, Iss. 1, (2018): 1483-1493. DOI:10.15243/jdmlm.2018.061.1483.

20. Ying Li, Y.-h. C.-Y. (2019). Coal production efficiency and land destruction in China's coal mining industry. Resources Policy, vol. 63, no. April, p. 101449, 2019, doi: 10.1016/j.resourpol.2019.101449.

21. Zikri Habibie Muhammad Akrim, F. M. (2019). Study of Manufacture Company Strategy in Implementing ISO 9001:2015 \& ISO 140001. Universitas Negeri Makassar Environmental Journal, vol. 2, no. April, pp. 28-33, 2019. 